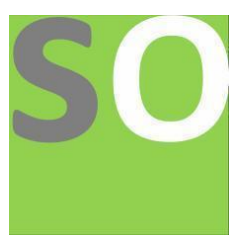

Article title: Responding to access and beyond in Fee-free policies: Comparative Review of Progressive Free Senior High and Free Senior High School policies in Ghana

Authors: Gabriel Asante[1], David Agbee[2]

Affiliations: Corvinus University of Budapest, Hungary[1], University of Ghana[2]

Orcid ids: 0000-0002-5635-0638[1]

Contact e-mail: gabito207@gmail.com

License information: This work has been published open access under Creative Commons Attribution License http://creativecommons.org/licenses/by/4.0/, which permits unrestricted use, distribution, and reproduction in any medium, provided the original work is properly cited. Conditions, terms of use and publishing policy can be found at https://www.scienceopen.com/.

Preprint statement: This article is a preprint and has not been peer-reviewed, under consideration and submitted to ScienceOpen Preprints for open peer review.

DOI: 10.14293/S2199-1006.1.SOR-.PPIEK9M.v1

Preprint first posted online: 02 June 2021

Keywords: Public policies; Secondary education; School access; Progressive Free Senior High School; Free Senior High School; Ghana 


\title{
Responding to access and beyond in Fee-free policies: Comparative Review of Progressive Free Senior High and Free Senior High School policies in Ghana
}

\author{
Gabriel Asante and David Agbee
}

\begin{abstract}
The study compares two fee-free policies at the upper secondary level in Ghana on how they responded to access and the policymaking processes in education. Secondary sources of data were used while Haddad and Demsky's framework of education policymaking served as the theoretical basis for textual data analysis. The results show that Free Senior High School policy responded to the program output of an increase in access, unlike Progressive Free Senior High policy. However, the inconsistent release of funding and limited stakeholder consultation are common features of the policies. It is further observed that the desirability of access is over prioritised in the current Free Senior High School policy, leaving gaps in educational facilities and resources during policy decision. To address these challenges, sources of funding must be re-assessed for possible policy redesign that invites consumers of the policy who opt for boarding status to absorb a proportion of boarding fees.
\end{abstract}

Keywords: Public policies; Secondary education; School access; Progressive Free Senior High School; Free Senior High School; Ghana 


\section{INTRODUCTION}

Education is regarded as a major drive for human capital formation, poverty reduction, promoting social mobility, a determinant of political participation, and a necessary precursor for democratic and institutional quality (Barro, 1999; Becker, 1993; Harber, 2002; Shuaibu \& Oladayo, 2016). Developing countries mindful of the direct and indirect benefits of education have been developing educational policies to improve their educational systems. Haddad and Demsky (1995, p. 18) functionally defined policy as 'an explicit or implicit single decision or group of decisions which may set out directives for guiding future decisions, initiate or retard action, or guide implementation of previous decisions.' However, over the years, the attention of policymakers in developing economies such as Sub-Saharan Africa (SSA) has been to improve basic education due to the idea that investment in higher education would yield lower social returns than those in lower levels (Heyneman, 2003). This was reasonable for economic growth and social justice, where most citizens needed access to basic education than higher education (Archer et al., 2005).

With the adoption of many international protocols such as the Education for All (EFA) and the World Education Forum at Dakar in 2000 under Millennium Development Goals (MDGs), enrolment at the basic level (primary and lower secondary) have relatively improved (Lewin, 2009; Little \& Lewin, 2011). However, the transition to upper secondary education has been challenging over the years. This raises a major concern, taking into consideration the target of countries to meet Sustainable Development Goal (SDG) 4.1 of primary and secondary education for all by the year 2030. With less than ten years to the deadline of this target, SSA records an average of 34\% of its youth of upper secondary schooling age in school (UIS, 2021).

Ghana is not an exception from this general outlook in SSA. The country has pursued a range of policies at the basic level to promote access such as Free Compulsory Universal Basic Education (FCUBE), Capitation Grant, and School Feeding Programme (Akyeampong, 2009; Ampratwum \& Armah-attoh, 2010; Pajibo \& Tamanja, 2017). However, the transition to upper secondary is low. According to the Ministry of Education (2018a), out of 100 children who enter Primary 1, 41 enter upper secondary and 38 complete indicating an internal inefficiency in the education sector. Figure one shows the trend in gross enrolment rate at different levels of pre-tertiary education from 1999 to $2019 .{ }^{1}$ Nevertheless, Ghana presents a particularly interesting case of education policies to increase enrolment at the upper secondary level. In the past few years, new priorities of politicians and policymakers have emerged at the post-basic education level. The country has introduced two fee-free policies by two different governments since 2015. They are Progressively Free Senior High School (hereinafter: PFSHS) and Free Senior High School (hereinafter: FSHS) policies.

\footnotetext{
${ }^{1}$ Due to the presence of over-aged enrolment, the values can exceed $100 \%$.
} 


\section{Gross enrolment ratio}

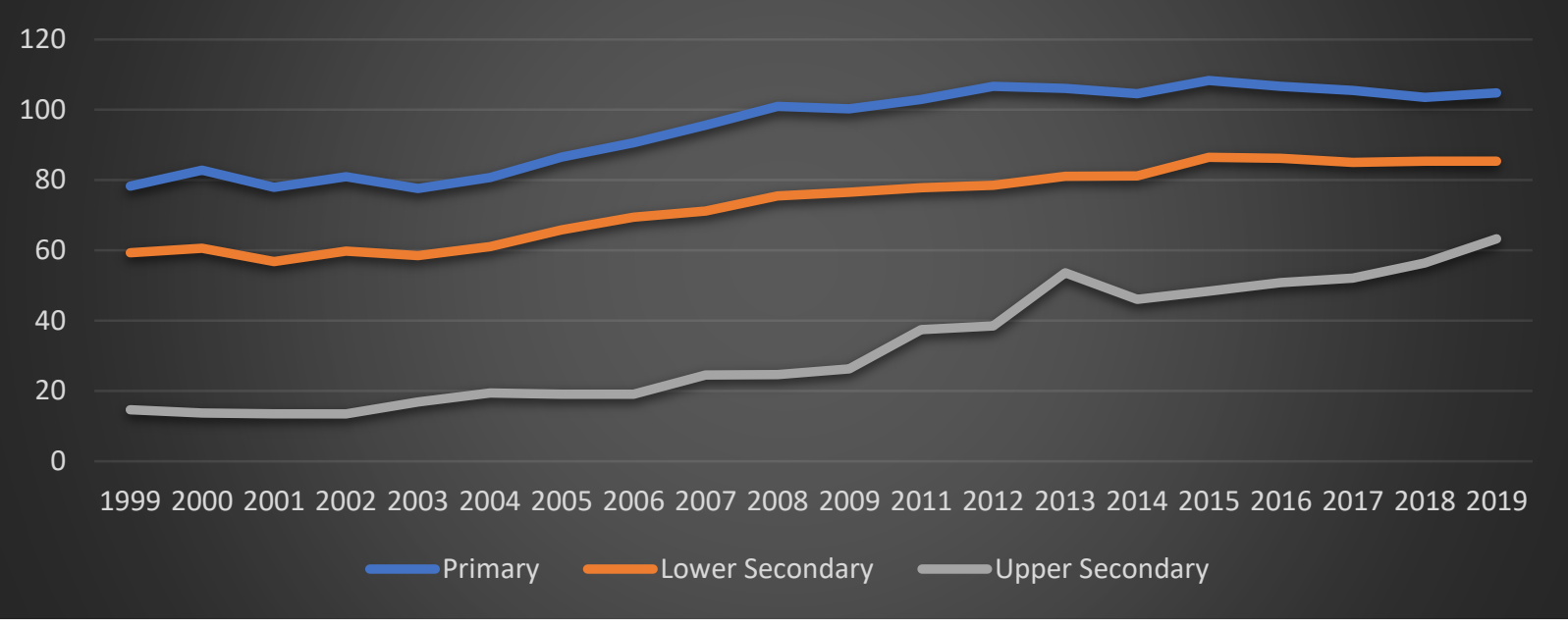

Figure 1: Trend in the level of access in pre-tertiary education in Ghana

Source: (UIS, 2021)

The objective of this paper is to undertake an ex-post analysis of the two fee-free policies from a comparative perspective. This is intended to identify the strengths and weaknesses related to the two policy options where the strengths could be improved, and weaknesses resolved concerning the current policy of FSHS adopted in 2017. This study is different from other studies in fee-free policies in Ghana and elsewhere in several important dimensions. Previous studies either focused on the evaluation of only FSHS (Essuman, 2018; Mohammed \& Kuyini, 2021); FSHS effects on quality university education (Adu-Gyamfi et al., 2020); FSHS challenges and ways to improve it (Asumadu, 2019); the appropriateness of the replacement of PFSHS with FSHS (Abdul-Rahaman et al., 2018); or fee-free policies and its effects on teachers and headteachers and income of male and female teachers (Chapman et al., 2010; Molyneaux, 2011). This study evaluates two fee-free policies concurrently on how they responded to the problem of school access that is the low rate of transition from lower secondary to upper secondary. It also evaluates the policies on how education policymaking processes reflect fee-free policies in Ghana. Through comparative case study design, data is collected from integrated literature review comprising documents, media reports and published articles. Textual analysis is used as the method of analysis. The rest of the paper is organised as follows. The next section put the paper into perspective by reviewing the conceptual structure of the education policymaking process from Haddad and Demsky's (1994, 1995) perspective. This is followed by an overview of the educational system in Ghana and a description of the two policies under consideration. Thereafter, the method of study is discussed. The analysis and results are presented then the concluding remark with discussion on proposals for fee-free policies in Ghana and further research avenues. 


\section{CONCEPTUAL MODEL}

\section{Education policymaking Process}

The education policymaking process is intensive and comprehensive. The policy made must be wise, in the sense that it does not cause new educational problems in the sector. Education is hinged on three principles: access, quality, and relevance. Education policies that are made must encourage access, quality, and internal and external efficiency (Haddad \& Demsky, 1995). Haddad and Demsky $(1994,1995)$ offer a framework for educational policy analysis synthesising from Lindblom's $(1958,1959)$ incremental methods of policymaking as well Allison and Zelikow's (1999) discussions of the rational actor, organisational process and government politics models in decision making. Other frameworks for education policymaking exist, for example, Cooper, Fusarelli, and Randall's (2004) four frameworks of normative, structural, constituent and technical. However, Haddad and Demsky's $(1994,1995)$ framework presents a comprehensive dimension in which education policymaking thrive especially in developing countries. The comprehensive nature and the focus of the framework on developing economies make an appropriate choice for this study. Haddad and Demsky's sequence of events consists of eight policy processes. ${ }^{2}$ They are analysis of the existing situation, generation of policy options, evaluating policy options, making the policy decision, planning for implementation, policy implementation, policy impact assessment and subsequent policy cycles. These eight policy processes can be grouped under the pre-policy decision, the decision process itself and post-decision activities.

\section{Pre-policy decision}

Haddad and Demsky's $(1994,1995)$ framework lists analysis of the existing situation (problem) as the first step in education policymaking. A policy in education must be a response to a problem in the sector. The sector's problem is analysed with other variables, for example, the country's population, location, political context, economic context and level of economic development. The education sector itself needs to be analysed. This can be analysed by: i) assessing access to educational opportunities, either from the demand side or supply side (Hunt, 2008), ii) equity in the distribution of educational services for example distribution according to region, rural-urban, sex and socio-economic status, iii) structure of the education, iv) internal efficiency, for example, the efficiency of teaching and learning system, utilisation of teachers and physical facilities, and the efficiency of learning (quality of teachers and curricula), v) external efficiency that is the relationship between schooling and the labour market and vi) institutional arrangement for the management of the sector (Haddad \& Demsky, 1994).

\footnotetext{
${ }^{2}$ In their 1995 publication, they specified seven processes instead of the eight steps specified in the 1994 publication. They combined planning for implementation and policy implementation into one step in the 1995 publication.
} 
The second stage is the generation of policy options. The policy option is generated through the context of a perturbed problem, political decision, or reorganization scheme. This can arise out of a systematic mode, incremental mode, ad hoc mode, or importation mode. The systematic mode involves the generation of data through the identification and analysis of issues or research synthesis and comparative indicators. The incremental mode arises out of a public debate about an educational issue that calls for immediate action to maintain legitimacy. The urgency cause policymakers to generate policy option without considering all the facts with the hope of incremental improvement in the future. The ad hoc mode means that problems may arise out of the educational sector and requires the sector to adjust. The importation mode arises from foreign specialist operating as consultants to introduce innovations to the educational system. The third step is the evaluation of policy options. This is the stage of ex-ante policy analysis (Bardach, 2012). ${ }^{3}$ The imagined outcome of the intended policy option is compared with the present situation to assess their feasibility, desirability, and affordability (Haddad \& Demsky, 1994, 1995). Feasibility is the assessment of staff and their capability, resource personnel and time. The interest group and stakeholders (for example parents and students) in the policy options are assessed in the desirability as well as the political capital for political elites. For example, a political party that has promised access to education for all will consider a policy option that gives more access to all than one that restricts access. Affordability is the monetary cost, opportunity cost and political cost of the policy option. Monetary cost entails the fiscal responsibility (public purse) to afford the policy option or invite consumers to share the proportion of the cost. Opportunity cost examines other benefits in the education sector which may need to forgo due to a certain policy option. In the fourth stage, a policy decision is made (adoption). The policy decision is made by balancing several factors analysed including data, finance, time, personnel, interest groups, stakeholders' demands and the political capital and cost.

\section{The decision process itself}

In the decision process itself, planning for policy implementation is the first step. Financial resources, technical knowledge, schedules, physical resources, and administrative system all need to be clearly stated and structured to carry out the policy decision. Here, it is important to enabling consumers and providers of the policy to embrace the new change through political support. It is important, indeed, to mention that the stakeholders such as teachers, students, parents, and administrators should all accept the new policy as their own as well as in the interest of the state. The policy change reaches the implementation stage which can generate new policies. Policy implementation generates modifications due to circumstances of implementation not anticipated in the planning stage or the feedback obtained calls for re-assessment and subsequent modification.

\footnotetext{
${ }^{3}$ See Bardach (2012) for his 'eightfold path’ which details ex-ante policy analysis.
} 


\section{Post-decision activities}

Impact assessment is undertaken after policy implementation. The impact assessment is about the policy objectives which is beyond the output of the policy goal. Here, the cost of financing, the quality of students' outcome and the efficiency of the policy are assessed. Subsequent policy cycles arise out of the assessment as the final stage in the cycle. We summarise the eight processes within the three main stages in figure two.

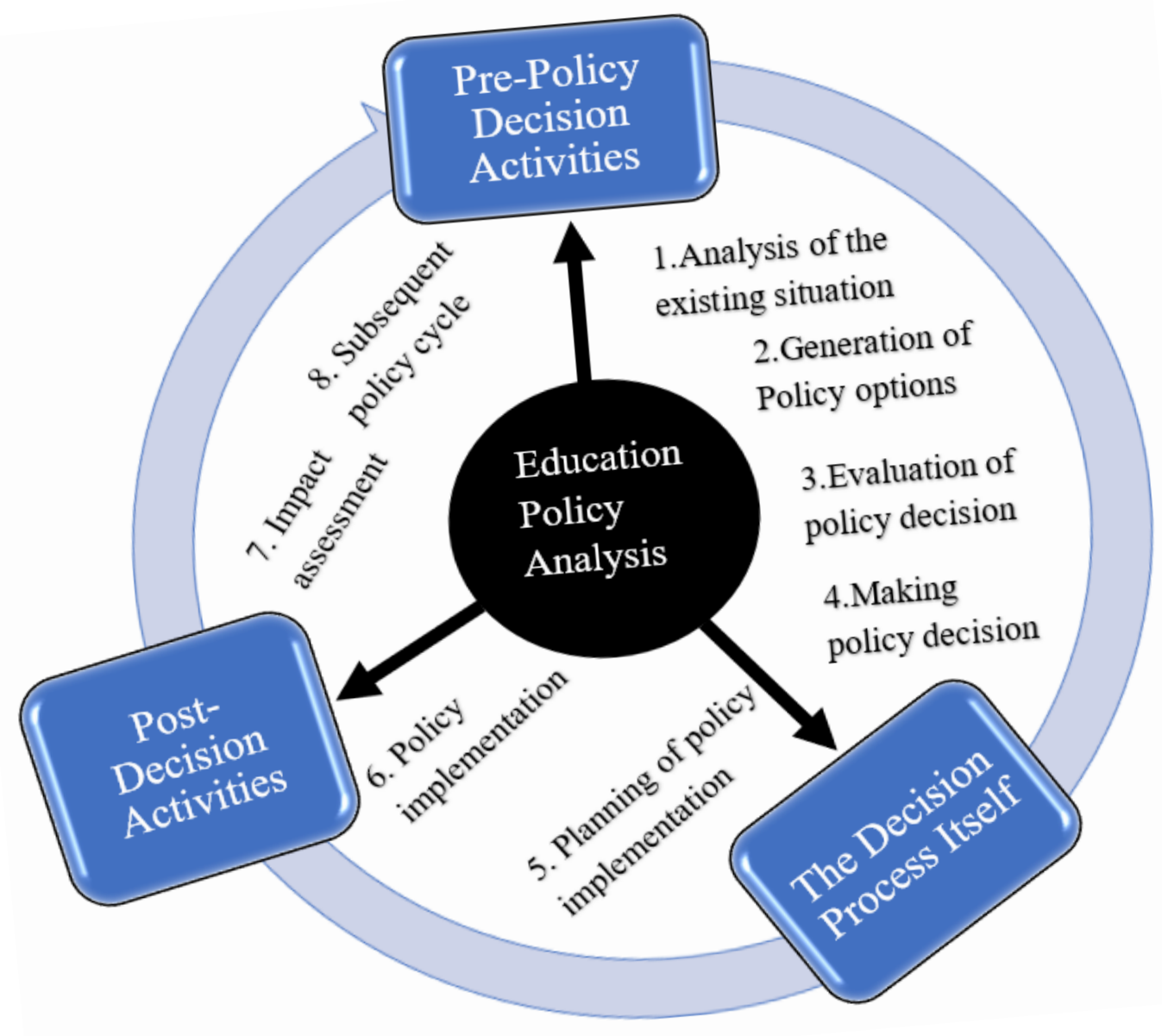

Figure 2. Summary of education policymaking framework adapted from Haddad and Demsky (1994, 1995). 


\section{OVERVIEW OF GHANA'S EDUCATIONAL SYSTEM}

The educational system in Ghana follows a 6-3-3-4 system. That is six years primary, three years lower secondary, three years upper secondary and four years bachelor's. Primary and lower secondary constitute basic education. This level of education is free and compulsory. At the end of lower secondary school (also called Junior High School (JHS)) Form 3, students write exit exams for Basic Education Certificate Examination (BECE) in seven subjects. Students are required to select their choice of upper secondary schools and are placed and enrolled in one of the schools selected through the Computerised School Selection and Placement System ${ }^{4}$ after successfully passing the BECE.

\section{Upper secondary education}

Upper secondary education covers three years of Senior High School (SHS) or Technical, Vocational Education and Training (TVET). Subjects taught in upper secondary schools are English, Mathematics, Integrated Science, and Social Studies as core subjects. Every student takes these subjects. Each student also takes three or four Elective subjects, chosen from one of seven groups: General Sciences, General Arts (social sciences and humanities), Vocational (visual arts or home economics), Technical, Business, or Agriculture. Students take exit exams known as the West Africa Senior Secondary School Certificate Examination (WASSCE) at the end of the threeyear education organised by The West Africa Examinations Council (WAEC).

\section{Agenda Setting and Fee-free Policies in Ghana}

According to Kingdon ((2013), agenda-setting is the recognition of a problem on the part of the government. The recognition of access to education for Ghanaians is emphasised in the country's 1992 constitution as a legal framework. Article 25 (1) states:

All persons shall have the right to equal educational opportunities and facilities and with a view to achieving the full realization of that right-

(a) basic education shall be free, compulsory and available to all;

(b) Secondary education in its different forms, including technical and vocational education, shall be made generally available and accessible to all by every appropriate means, and in particular, by the progressive introduction of free education (Ghana, 1993).

Beyond the legal framework, the recent recognition of access to senior high school education has sparked a debate between the two leading political parties in the country namely, New Patriotic Party (NPP) and the National Democratic Congress (NDC). They have been at the opposite side of canvassing for the alternative means which seeks to address the continuing low access to high school education. Putting this on the agenda was ignited by NPP in 2008 - the then ruling

\footnotetext{
${ }^{4}$ See Babah, Frimpong, Mensah, and Acquah (2020) for a systematic review of this system.
} 
government seeking re-elections in the country's 2008 general elections when they promised in their manifesto to 'guarantee access to all children of school-going age to free quality education at the basic school level. This will be extended to cover Senior High School education as well' (NPP, 2008, p. 69). However, their party lost the presidential elections. Interestingly, NDC in 2012 general elections focused its debate on the constitutional provision of 'progressive introduction' which they promised that 'the government of the NDC...is equally committed to the progressive introduction of free secondary education under Article 25(1) (b)' (NDC, 2012, p. 20). They emphasised quality, adequate and reliable infrastructure which needs to be put in place to accommodate the growing population.

These focusing events marked the beginning of fee-free education policy in its larger form on the national agenda (Ayee, 2016). Manifestos set national agenda because they play an important role in elections (Caplan, 2007) in which political parties prepare and outline their policies and program proposals. Following this, two fee-free policies have been adopted and implemented at the upper secondary school level in Ghana. They are Progressive-ly Free Senior High School policy by NDC and Free Senior High School policy by NPP.

\section{Progressive-ly Free Senior High School policy (PFSHS)}

PFSHS was implemented in September 2015 by the NDC government. It was a form of partial funding for the reduction of the cost of senior high education to some students. Specifically, students were exempted from paying the following costs of education; examination fees, entertainment fees, library, Students Representative Council (SRC) dues, sports fees, culture fees, science development and mathematics quiz fees, Information and Communication Technology (ICT) fees and co-curricular fees for day students in public senior high schools (MoF, 2015).

\section{Free Senior High School Policy (FSHS)}

FSHS replaced PFSHS policy in September 2017 when NPP was re-elected to office in January 2017. The policy absorbs all direct cost of schooling and other indirect costs throughout upper secondary school institutions in the country (Abdul-Rahaman et al., 2018). In summary, PFSHS was limited in scope and coverage where full tuition and admission fees or registration fees were not absorbed by the government for all students while FSHS is holistic, absorbing all fees for all students throughout the country.

From the foregoing, the study asks, and it is guided by the following research questions:

1. How did PFSHS and FSHS respond to the existing problem of the low rate of transition from lower secondary to upper secondary school in Ghana?

2. How are the policy processes in education policymaking reflect in the adoption and implementation of fee-free policies in Ghana?

3. What challenges confront the implementation of the current FSHS and how can they be overcome? 


\section{METHODS}

The unit of analysis is a policy field that is fee-free policies at the upper secondary school level with two cases $(N=2)$ set within one country in a comparative perspective. The study is underpinned by the constructivist paradigm which allows a researcher to construct meanings through the engagement with real-world happenings (Creswell, 1998). The data is collected through an integrated literature review of published and unpublished documents and media reports. An 'integrated literature review is a form of research that reviews, critiques, and synthesises representative literature on a topic in an integrated way such that new frameworks and perspectives on the topic are generated' (Torraco, 2005, p. 356). The research design is a comparative case study. Comparative case-oriented studies are suitable when researchers want to have a grasp of 'cases because of their intrinsic value' (Ragin, 2014, p. 35). Since the method for this research was reviewing existing data, a textual analysis was used as the method for analysis.

An extensive desk-based review of educational policies and policy debates on fee-free policies is conducted. Specifically, we review all available Ghana Senior High School-related educational access scholarly literature published in English. Media reports from news and organisations' websites are carefully examined and cross-examined with other sources to verify the authenticity of the information. This was deemed appropriate considering that the available scholarship did not provide all the required information to undertake the review. The search engines used for the study are Google Scholar, Scopus database, SAGE, SPRINGER Journals online, JSTOR, Sci-hub database, WorldCat, and Google search. The search was guided by search words such as fee-free education, free education, Ghana free SHS, high school education, secondary education, school enrolment, WASSCE results, and double track. The comprehensive review of documents and media reports is undertaken under the three main broad themes of Haddad and Demsky's (1994, 1995) education policymaking analysis cycle. That is the pre-policy decision, the decision itself, and post-decision.

\section{FINDINGS}

\section{Pre-policy decision}

\section{Analysis of the existing problem}

Fee-free policies are access-oriented policies designed to offer free education to children and the youth at different levels of education (World Bank, 2009, p. 1). In this regard, the main objective of fee-free policies, among others, is to increase access to education. Table one shows the trend in BECE candidates eligible to enrol in Senior High Schools, students placed, students enrolled in the first year and percentage placed but not enrolled from 2013 to 2018. Before the implementation of fee-free policies, an average of $27.5 \%$ of students placed in high school did not enrol. Several 
possible mechanisms may prevent qualified students to enrol. This can emanate from demand-side factors such as health, child labour, pregnancy or no interest. It can also originate from supplyside factors such as unavailability of schools (lack of school supply) or poor quality of education (Hunt, 2008). However, several studies have demonstrated that the most common factor preventing qualified students to enrol in Sub-Saharan Africa and Ghana, in particular, is poverty (Amagnya, 2020, pp. 112-113; Duflo et al., 2017; Sabates et al., 2010; World Bank, 2009). This is because economic poverty causes the inability to afford the direct cost (especially registration fees and tuition fees), the indirect cost and the opportunity cost of schooling (Bray, 2007; Sabates et al., 2010).

Table 1: Analysis of the trend in school access before and during fee-free policies

\begin{tabular}{|l|c|c|c|c|c|c|}
\hline & \multicolumn{2}{|l|}{$\begin{array}{l}\text { Before Fee-free } \\
\text { policies }\end{array}$} & \multicolumn{2}{l|}{$\begin{array}{l}\text { Progressive Free } \\
\text { SHS period }\end{array}$} & \multicolumn{2}{l|}{ Free SHS period } \\
\hline Item/Year & $\mathbf{2 0 1 3}$ & $\mathbf{2 0 1 4}$ & $\mathbf{2 0 1 5}$ & $\mathbf{2 0 1 6}$ & $\mathbf{2 0 1 7}$ & $\mathbf{2 0 1 8}$ \\
\hline The trend in total Registered BECE & 391032 & 422946 & 440469 & 461009 & 468060 & 521710 \\
\hline \% Change in BECE registrants & & $\mathbf{8}$ & $\mathbf{4}$ & $\mathbf{5}$ & $\mathbf{2}$ & $\mathbf{1 1}$ \\
\hline Total Registrants of Private BECE & & & $\mathbf{1 1 8 1}$ & $\mathbf{1 4 1 8}$ & $\mathbf{1 3 7 9}$ & $\mathbf{1 1 8 8 6}$ \\
\hline Students placed in the First year & 352202 & 386412 & 415012 & 420135 & 424224 & 486354 \\
\hline Students Enrolled in the First year & 261598 & 273152 & 299649 & 308799 & 361771 & 431844 \\
\hline \% Placed but not enrolled & $\mathbf{2 6}$ & $\mathbf{2 9}$ & $\mathbf{2 8}$ & $\mathbf{2 7}$ & $\mathbf{1 5}$ & $\mathbf{1 1}$ \\
\hline
\end{tabular}

Sources: (Bonney, 2021; MoE, 2018b; Opoku Prempeh, 2019; WAEC, 2021a).

In 2015, when PFSHS was introduced, 28\% of students placed in high school did not enrol and it decreased to $27 \%$ in the second year. This is an average of $27.5 \%$ which is comparable to the prepolicy era. Therefore, the introduction of the policy did not make a significant difference in responding to the existing problem. With the introduction of FSHS in 2017, the percentage of students placed but not enrolled decreased from $27 \%$ to $15 \%$ in the first year, and $11 \%$ in the second year. This is the lowest rate compared to the previous years with about 16 percentage points improvement from 2016 and an average of $13 \%$ for the two years.

From the historical trend, it can be argued that FSHS responded to the problem of the existing situation in Haddad and Demsky's (1994) framework, unlike PFSHS. The existing situation is the inability of qualified students placed in high school to enrol (transition from lower secondary to 
upper secondary) in most cases due to poverty. Many students enrolling in high school during the introduction of FSHS may be explained by two factors. First, because the policy is holistically feefree where neither day nor boarding students pay any form of fees including registration or admission fees. Two, the data from the trend in total registered BECE students showed that there is an increase of $11 \%$ of students registering in 2018 indicating people interest to have the opportunity to enrol in high school compared to previous years. Nevertheless, this increase in BECE registrants in 2018 may partly be due to population growth. However, comparing the trend from 2013 to 2017 with a percentage increase of $8,4,5$ and 2 percentage points respectively, it can be argued that interest in FSHS in 2018 played a significant role in the 11 percentage points increase. This is further supported by the trend in total private BECE registrants. This programme, implemented in 2015, gives candidates who did not perform well in the examination previous years an opportunity to improve on their grades to continue with their education to senior high school. The significant improvement in total registrants of 11,886 in 2018 shows that there was a particular interest in 2018 for many youths to get the opportunity to be placed and enrol in high school because it is wholly free. The inability of PFSHS to respond to the existing situation could be attributed to the continuous charging of registration fees (admission fees) to all students and tuition fees to some students. These cost components, as argued, are the significant barriers causing the low transition to high school (Bray, 2007).

\section{Beyond access}

\section{Generating policy options}

There are some similarities as well as differences in the policy options of PFSHS and FSHS. In generating the policy options, PFSHS focused on the vulnerable, deprived institutions and mostly day students (Citifmonline, 2015). This policy option according to the government is to respond to equity in the distribution of educational services. A statement from the Ghana Education Service (GES) on the rollout of the policy stated that the need to make SHS progressively free by the government was to help vulnerable groups by removing financial barriers and improving access to SHS and addressing inequalities in opportunities to transition from JHS to SHS. FSHS on the other hand covered all direct costs of schooling including other indirect costs such as feeding for all day and boarding students. Consumers of the policy pay no direct cost. However, the policy began with first-year students who enrolled in 2017. Continuing students were not covered. These policy options have the characteristics of incremental modes as policymakers needed to assess the nature of the policies for full implementation to take effect. Radical change is less seen in the two policy options. However, a distinction can be made. FSHS had a clear timeline when the policy option will have full cycle coverage, which is three years of implementation. With PFSHS, the timeline for full coverage was not specified. No evidence of systematic and importation modes is identified in the policy options. Evidence of the full range of data gathered and options prioritised and refined is limited. In addition, there is no evidence of the policy introduced by the international community. 


\section{Evaluating policy options and Making policy decisions}

In evaluating policy options, apart from the desirability of the policy option, the feasibility and affordability of the policy must be assessed so that the policy does not lead to further problems in the education system. The policy may be desirable to promote access. However, the unavailability of funds to finance the policy leads to unsuitability and debts to public schools creating other problems in the education system. The funding for PFSHS is heavily criticised as it is revealed that funds needed to support the policy were not subsequently released to schools as adopted. The Conference of Heads of Assisted Secondary Schools (CHASS) ${ }^{5}$ in 2019 demanded areas of funds for PFSHS. In a letter to GES, the coalition indicated outstanding arrears from the implementation of PFSHS creating;

a backlog of debts in the schools. Hence any funds sent to the schools [subsequently] are met with suppliers coming to the schools to redeem debts we owe them. We would be very happy if these funds are released to the schools without any further delay (Ansah, 2019).

It seems that the policy was left to programme managers without a clearly defined subsequent financing scheme. The problem of feasibility or affordability in a policy option concerning the release of funds to schools is not peculiar to PFSHS. In the third term of the first academic year of FSHS implementation, school managers reported a delay in the release of funds to schools. In a letter from CHASS on May 28, 2018, entitled 'Delayed payment of third term (2017/2018) Free SHS grant to Senior High Schools', they indicated that the delay in the release of funds is 'creating serious financial challenges for Senior High Schools'. In the $7^{\text {th }}$ week of re-opening school out of the 14 weeks schools are supposed to be in session, no funds were released to schools (Yanney, 2018).

\section{The policy decision process itself}

Planning of policy implementation and policy implementation

To demonstrate political support in the planning of the policy implementation, each of the policies was launched by the president (head of the executive arm of government) at the time. His Excellency John Dramani Mahama launched PFSHS in 2015 while His Excellency Nana Addo Dankwa Akufo-Addo launched FSHS in 2017. To involve consumers of the policies, the launching occurred in the presence of students, teachers, headteachers, traditional leaders, school administrators and the general public.

\footnotetext{
${ }^{5} \mathrm{~A}$ coalition of headteachers (head of management) of public senior high schools.
} 
In a press release by the GES ahead of the PFSHS implementation, a total of 313,363 day-students selected from 580 schools across the country were to benefit from the policy (Allotey, 2015; Citifmonline, 2015). In the first year of implementation, an amount of GHS 12,178,544 (approximately $\$ 2.7$ million) was released to fund the policy in the first term of implementation (MoE, 2015). With FSHS, the government budgeted GHS400 million (approximately $\$ 90$ million) for the first academic year thus 2017/2018 (MoE, 2017). The wide difference in the cost of finance is due to the limited coverage of PFSHS and the wide coverage of FSHS. In FSHS, all cost components are absorbed, and it includes boarding students as well. Fees for students with boarding status are relatively higher than fees for day students due to the cost of accommodation and feeding for students with boarding status. For example, in the 2019/2020 academic year, the summary schedule fees per head for first-year day SHS students was GHS953.45 and GHS1,391.30 for boarding students and GHS1,069.95 and GHS1,507.80 for TVET students, respectively. Continuing students in SHS and TVET fees was GHS463.45 and 479.95 respectively for day students and boarding fees was GHS897.80 and GHS914.30, respectively (MoE \& GES, 2021). Fees for a continuing boarding student is almost two times the fees of a continuing day student.

The launch of PFSHS was occasioned by the commissioning of community day senior high school infrastructure. The community day senior high school project is a government of Ghana and the World Bank partnership infrastructure project under the Ghana Secondary Education Improvement Project (SEIP) to construct and expand school infrastructure (World Bank, 2014). The infrastructure development is argued by the NDC government to spearhead a complete overhaul of all school fees so that a rapid increase in enrolment will have the corresponding infrastructure to absorb students. On personnel, funds were released to recruit additional 9300 personnel to staff new schools being commissioned. At the launch of FSHS, the president indicated the government's continuity on the expansion of infrastructure to accommodate students. He states: 'Government is collaborating with various partners to implement major programmes and interventions such as the Secondary Education Improvement Project (SEIP), the expansion of physical infrastructure' (Republic of Ghana, 2017).

Nevertheless, in the second year of FSHS' implementation, enrolment figures exceeded the number of available seats to accommodate students. After one year of implementation, additional 13,200 seats were created with total available seats of 290,737 whilst 472,730 seats were needed, creating a gap of 181,993 (Opoku Prempeh, 2019). Indeed, the decision of FSHS was put to test at this stage (Haddad \& Demsky, 1994, pp. 225-257). This led to re-assessment and modification of the policy. The Minister of Education indicated, 'even if we have all the funds we cannot build quick enough for 2018 entrants' (MoE, 2018b). Clearly, the overwhelming increase in enrolment that outnumbered available seats was not thoroughly evaluated during the policy option evaluation stage introducing 'some surprises' to decision-makers.

Beyond access in fee-free policies, insufficient and delay in the release of funds have characterised access-oriented basic education policies in Ghana such as the Capitation Grant and School Feeding 
Programme (Ampratwum \& Armah-attoh, 2010; Pajibo \& Tamanja, 2017). This seems to continue in access-oriented interventions at the upper secondary education. Apparently, the cost of funding FSHS is higher than PFSHS due to its holistic nature. The reliance on oil revenue as the major source of funding of FSHS has been criticised for its sustainability due to the inelastic nature of oil necessitating the need for alternative sources of funding (Mohammed \& Kuyini, 2021). The finance minister in 2018 gives a hint of the huge cost of FSHS to the public purse during the implementation stage which indicated that the full cost of the FSHS policy option was not thoroughly assessed based on data at the ex-ante stage. In a television interview, he indicated 'Free SHS could be targeted instead of wholesale'. He continued:

True, it may be that there have to be changes in the way we are administering it. I can't take my child to Achimota [school] or Odorgonno [SHS] and leave him or her there and drive away and not pay for anything whiles I can pay for ten people (Nyabor, 2019).

This follows an assessment by other Civil Society Organizations and coalitions such as the National Association of Graduate Teachers of the need to adapt to the means-testing scheme due to the huge cost of the policy to the public (Adogla-Besaa, 2018; Nyabor, 2019). From the above, it can be argued that the FSHS policy option is desirable in increasing access, however, its affordability, long term feasibility and sustainability are in doubt. Haddad and Demsky (1995, p. 36) rightly pointed out that, 'implementation is the time when one discovers that schedules are unrealistic and that programmes are over-ambitious' which calls for re-assessment and re-design.

Of course, re-assessment and re-design during policy implementation are inevitable. The reassessment and modification of FSHS led to securing additional funds of GHS1.5billion through securitisation of Ghana Education Trust Fund (GETFund) to rapidly expand infrastructure (Opoku Prempeh, 2019). The single-track system (three-term school calendar) of senior high school was replaced with a double-track system (two-semester calendar). The double-track calendar system according to the minister 'is an intervention that allows schools to accommodate more students within the same facility and is often motivated by its potential to improve overcrowding as well as to save costs relative to new school construction in the short term' (MoE, 2018b). In the doubletrack system, some students can be on vacation while the building is in use year-round (H. Cooper et al., 2003). This system had been adopted in other countries such as United States (NAYRE, 2000). In Ghana's double-track system under FSHS, 400 out of the 696 public SHSs were selected where students are grouped according to two tracks: 'Gold Track' and 'Green Track'. Figure three shows a typical double-track calendar. 


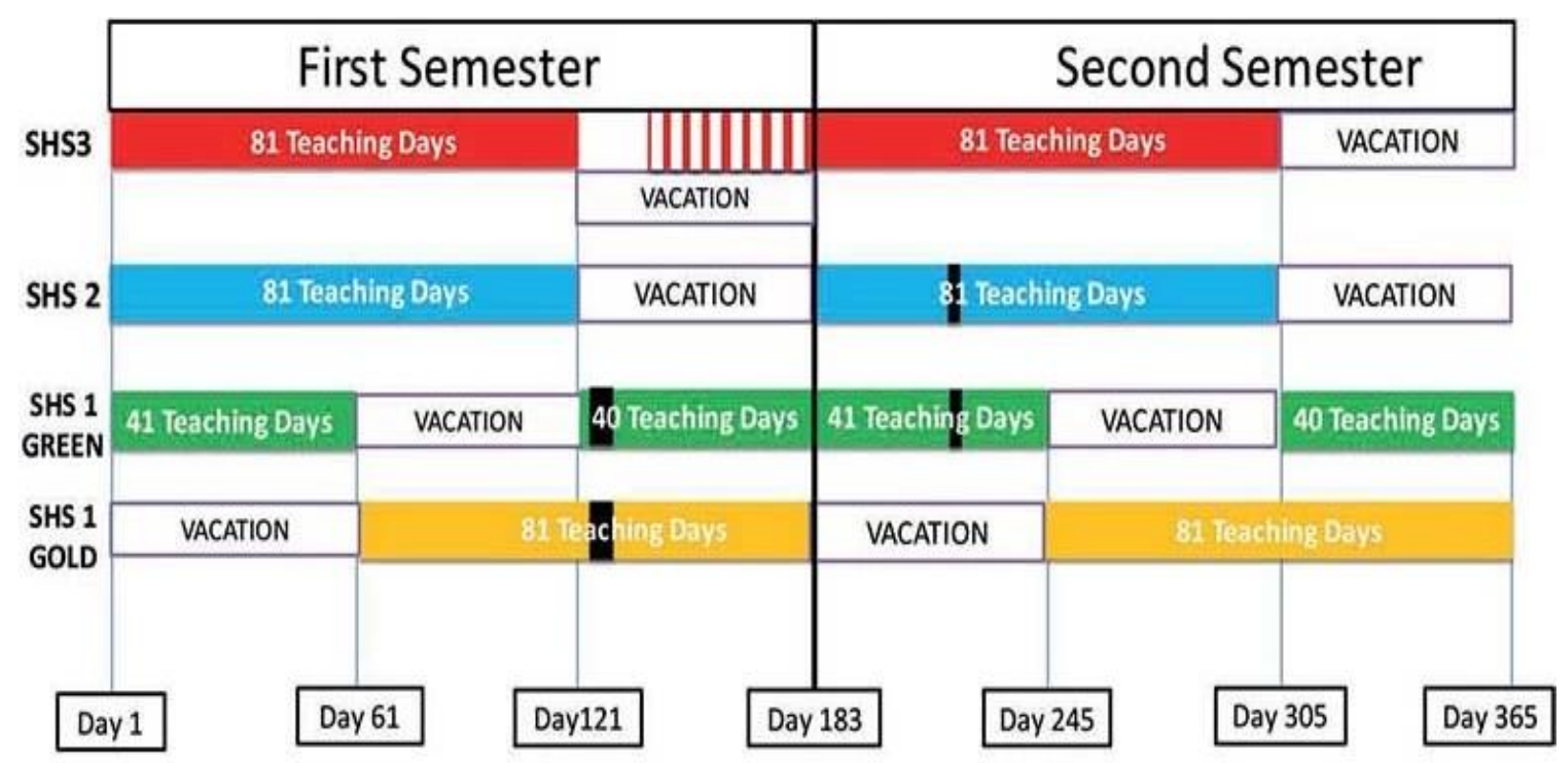

Source: Ministry of Education (2018b)

Figure 3: A typical double-track calendar for Ghana's Free SHS policy

The double-track calendar system has been criticised for the lack of communication on the new school system, no thorough engagement with stakeholders and inconsistent school reopening dates (GES, 2021; Matey, 2020; Mensah, 2019). A veteran journalist, Abdul-Malik Kwaku Baako reiterated: 'The points about parents not being fully made aware...I am prepared to concede that there might have been a gap in terms of making them understand what the issues were about and what the pressures and challenges would be relative to their children' (MyJoyOnline, 2018). On administrative management, the implementation of PFSHS was solely managed by the traditional school management body that is Ghana Education Service. In the case of FSHS, in addition to the traditional management body playing its role, the Free SHS Secretariat was set up to coordinate the implementation. Stakeholders in the education sub-system have criticised fee-free policies for no thorough stakeholders' engagement in the policy decision, planning and implementation. At a colloquium organised by the Institute of Educational Planning and Administration at the University of Cape Coast (IEPA-UCC) (2019), participants indicated the 'big gap between the Ministry of Education/GES and the [school] heads' regarding fee-free policies implementation. 


\section{Post-decision activities}

Impact assessment and subsequent policy cycles

In both policies, 30\% enrolment of students from 'less-endowed' basic schools to 'elite' senior high schools is seen as ensuring equity between the rural-poor and urban-rich communities (MoE, n.d.; Opoku Prempeh, 2019). Evidently, output assessment shows that access to secondary education increased with FSHS, unlike PFSHS. There was limited information on the issue of quality and relevance of the educational system in the implementation of PFSHS. The construction of school infrastructure was the notable communication. The academic curriculum remained unchanged.

With the introduction of FSHS, the deputy minister of education indicated in an interview:

We also have to understand that the architecture must be right, the system must be done in such a way that it is responding to the needs of the country. So yes, we have to look at access, you have to look at quality, we have to look at the relevance of the education system to the socioeconomic fortunes and transformation of this country (Ghanaweb, 2020).

A new curriculum that hinged on Science Technology Engineering and Mathematics (STEM) is introduced and the country indicated their preparedness to join Programme for International Students Assessment (PISA) in 2021 (MyJoyOnline, 2019). In addition, there is the Pre-Tertiary Teacher Professional Development and Management (PTPDM) and enforcement of the implementation of licensing and registration of teachers (MoE, 2018a; NDPC, 2017). Recruitment of teachers continued to staff new schools and run the double-track calendar (Kale-Dery, 2020).

Furthermore, we use grades scored in WASSCE for core subjects to assess the impact on the quality of schooling of the policies. We use core subjects only because all candidates take these subjects. Table two compares results from 2016 to 2020. The first and second batch of students enrolled on PFSHS took their exit exams in 2018 and 2019, respectively. The first batch of FSHS took their exams in 2020. From the average Tertiary Education Qualifying Grades (TEQG) that is grade A1-C6, candidates performed better in 2019 compared to previous years. An average of 63.22\% scored aggregate A1-C6 in all core subjects. This is the second batch of PFSHS. The first batch scored an average of 52.26\%. The first batch of FSHS scored an average of $60.07 \%$ which is better than the first batch of PFSHS but a decline from the performance of the second batch of PFSHS. However, for the first time, more than $50 \%$ of students scored the TEQG in all core subjects in 2020. In general, the performance of students enrolled in the fee-free policies is better than the pre-fee-free policies era. 
Table 2: Candidates' performance in WASSCE Core Subjects from 2016-2020

\begin{tabular}{|c|c|c|c|c|c|}
\hline \multirow[b]{2}{*}{ Year } & \multicolumn{2}{|c|}{$\begin{array}{l}\text { Pre fee-free } \\
\text { students }\end{array}$} & \multicolumn{2}{|c|}{ PFSHS students } & \multirow{2}{*}{$\begin{array}{l}\text { FSHS students } \\
2020\end{array}$} \\
\hline & 2016 & 2017 & 2018 & 2019 & \\
\hline Total Candidates & 274263 & 289207 & 316999 & 346098 & 375737 \\
\hline $\begin{array}{l}\% \text { of candidates obtaining } \\
\text { Tertiary Education Qualifying } \\
\text { Grades (TEQG) A1-C6 in the } \\
\text { English Language }\end{array}$ & 53.17 & 54.06 & 46.91 & 48.96 & 57.34 \\
\hline $\begin{array}{l}\% \text { of candidates obtaining } \\
\text { TEQG in Mathematics }\end{array}$ & 32.83 & 42.73 & 38.33 & 65.31 & 65.71 \\
\hline $\begin{array}{l}\text { \% of candidates obtaining } \\
\text { TEQG in Integrated Science }\end{array}$ & 48.48 & 43.66 & 50.52 & 63.17 & 52.53 \\
\hline $\begin{array}{l}\% \text { of candidates obtaining } \\
\text { TEQG in Social studies }\end{array}$ & 54.93 & 52.25 & 73.27 & 75.43 & 64.71 \\
\hline $\begin{array}{l}\text { Average TEQG for core } \\
\text { subjects }\end{array}$ & 47.35 & 48.18 & 52.26 & 63.22 & 60.07 \\
\hline
\end{tabular}

Sources: (Allotey, 2016; Frimpong, 2017; Teye-Cudjoe, 2018; WAEC, 2019, 2021b)

Empirical evidence of grades of students who enrolled under double track cannot be assessed because the second batch of FSHS, who are the first batch of the double-track calendar, are yet to take their exit exams. However, reviewing the performance of students of a modified calendar system in the United States, Cooper et al. (2003) and Graves (2010) find that the quality of academic performance on modified school calendars are poor especially in the first few years of implementation. Nevertheless, the system has some positive achievements for students from a relatively poor background. In addition, although students, staff, and parents have a positive experience with the system, these positivities depend on how well the system is communicated and involving community members in planning the system. With the above results from other countries, the evidence of inadequate thorough engagement with stakeholders and inconsistent school reopening dates about the double-track system of FSHS, there is an opportunity for further studies on the policy impact on school grades as the implementation of the policy continues. Another dimension of further studies on impact assessment is the external efficiency (relevance) of the policy. That is how the policy will respond to the job market demand. 


\section{CONCLUDING REMARKS}

The use of Haddad and Demsky's $(1994,1995)$ framework in education policymaking is robust to analyse all the major components of fee-free education policies in Ghana illuminating its advantage of a comprehensive framework. Maintaining registration fees (admission fees) and tuition fees components in PFSHS by the NDC government was not in sync with the main policy objective, which is increasing access. This is because these two cost components are demonstrated to be the major cost barriers to school access (Bray, 2007). Hence, maintaining these two cost components contributed to the low response of the policy to the existing problem that is the inability to transition from lower secondary to upper secondary. Apparently, the first stage in education policymaking did not reflect in PFSHS. FSHS responded to the existing problem by reducing the proportion of students who are placed in senior high school but could not enrol. It also raised the interest of many youths to enrol in high school. Certainly, the first stage in the education policymaking process reflected in FSHS.

However, access was over prioritised above other considerations such as infrastructure in FSHS during the policy decision and planning. The cost of the FSHS policy option was not thoroughly evaluated during the ex-ante analysis introducing major 'surprises' such as the lack of adequate school infrastructure and huge re-current expenditure during the implementation stage. The desirability to maintain legitimacy due to the long-held promise of free education for all setting the national agenda at the education sub-system compelled the NPP government to consider a holistic fee-free policy option. The problem of access in education has two sides; demand and supply (Hunt, 2008). Fee-free policy interventions must be formulated and implemented in relation to addressing other demand and supply dimensions. Nevertheless, the political capital of securing presidential re-election was obtained from FSHS due to its popularity among electorates while this did not manifest in PFSHS (Asekere, 2021; Frempong, 2020). These inferences support the conclusions of Mohammed and Kuyini's (2021) evaluation of the FSHS policy.

To conclude, available and safe infrastructure and timely release of funds for recurrent expenditure would require further government investment in the current FSHS policy. This can be achieved by re-assessing the sources of funding for the policy. With knowledge from Haddad and Demsky's framework under evaluation of policy options (affordability - monetary cost) (1994, pp. 23-24), we propose two re-assessment and redesign options. One, construct and complete Community Day Senior High Schools across the country. This is intended to improve the proximity of school supply to students. In this way, the government may invite consumers of the policy (parents and students) who opt for boarding status to absorb the proportion of boarding fees. The major difference in the fees schedule between day and boarding students emanates from feeding fees. Whilst feeding fees for a day student was GHS196.35 per semester in the 2019/2020 academic year, the cost for a boarding student was GHS686.40 per semester. Inviting consumers of boarding facilities to absorb the difference in feeding fees due to boarding status extends the concept of equity in the policy. This is because parents of day students borne the cost of renting nearby accommodation for their 
wards or the cost of transportation to school and the cost of living on their own or individual homes. Two, create a special revenue vehicle through taxation for the policy.

This study, however, is purely a literature review. No thorough interviews are conducted to gather other evidence that may support or disprove certain claims. Other studies may consider this methodological limitation for further studies. Nevertheless, the analysis and conclusions drawn here contain facts and information that could be reliably deployed for policy development and implementation by educational planners, policymakers and the government of Ghana as well as lessons to other governments in Sub-Sharan African countries implementing or intend to implement fee-free education at the upper secondary level.

\section{Disclosure statement}

No potential conflict of interest.

\section{Funding}

No funding is received yet for this project

\section{Data Availability statement}

All data generated or analysed during this study are included in this article and referenced appropriately.

\section{Notes on contributors.}

Gabriel Asante a is $\mathrm{PhD}$ candidate at the Corvinus University of Budapest, Hungary, Doctoral School of International Relations and Political Science. His research interests are education policies in developing economies, crime among youth, comparative public policy, and public administration.

David Agbee is a $\mathrm{PhD}$ candidate at Legon Centre for International Affairs and Diplomacy (LECIAD), School of Graduate Studies, University of Ghana. His research interests are Public Policy, Public Administration, Foreign policy, Defence Policy, African Security, International security, and Governance. 


\section{REFERENCES}

Abdul-Rahaman, N., Basit Abdul Rahaman, A., Ming, W., Ahmed, A.-R., \& S. Salma, A.-R. (2018). The Free Senior High Policy: An Appropriate Replacement to The Progressive Free Senior High Policy. International Journal of Education and Literacy Studies, 6(2), 26. https://doi.org/10.7575/aiac.ijels.v.6n.2p.26

Adogla-Besaa, D. (2018, July 24). 'Free SHS could be targeted instead of wholesale' - OforiAtta. Citinewsroom. https://citinewsroom.com/2018/07/free-shs-could-be-targetedinstead-of-wholesale-ofori-atta/

Adu-Gyamfi, S., Marfo, C., Nyaaba, A., Amakye-Boateng, K., Mohammed, A., \& Yartey, H. (2020). Free Senior High School (SHS) and Quality University Education in Ghana: The Role of the University Teacher. Journal of Educational and Social Research, 10(5), 225239. https://doi.org/10.36941/jesr-2020-0101

Akyeampong, K. (2009). Revisiting Free Compulsory Universal Basic Education (FCUBE) in Ghana. Comparative Education, 45(2), 175-195. https://doi.org/10.1080/03050060902920534

Allison, G. T., \& Zelikow, P. (1999). Essence of Decision: Explaining the Cuban Missile Crisis (Second Edition). Longman.

Allotey, G. A. (2015, September 17). Mahama to launch progressive free SHS policy today. Citinewsroom. https://citifmonline.com/2015/09/mahama-to-launch-progressive-free-shspolicy-today/

Allotey, G. A. (2016, August 9). 2016 WASSCE results out; 1,576 results cancelled.

Citinewsroom. https://citifmonline.com/2016/08/2016-wassce-results-out-1576-resultscancelled/

Amagnya, M. A. (2020). Factors Affecting Education in the Builsa District of Northern Ghana. Africa Education Review, 17(2), 104-121. https://doi.org/10.1080/18146627.2018.1530571

Ampratwum, E., \& Armah-attoh, D. (2010). Tracking Capitation Grant in Public Primary Schools in Ghana. Ghana Center for Democratic Development (CDD-GHANA), 10(1), 1-8. https://www.files.ethz.ch/isn/119433/2010-06_Volume10No1.pdf

Ansah, K. (2019, December 19). CHASS demands arrears of Mahama's Progressive Free SHS funds. Starrfm. https://starrfm.com.gh/2019/12/chass-demands-arrears-of-mahamasprogressive-free-shs-funds/

Archer, L., Hutchings, M., \& Ross, A. (2005). Higher Education and Social Class: Issues of Exclusion and Inclusion (1st Edition). Routledge. https://doi.org/10.4324/9780203986943

Asekere, G. (2021). The 2020 General Elections in Ghana: An Analysis of the Issues, Voting Pattern and Impact. Social Sciences, 10(1), 15. https://doi.org/10.11648/j.ss.20211001.13 
Asumadu, E. (2019). Challenges and Prospects of the Ghana Free Senior High School (SHS) Policy: The Case of SHS in Denkyembour District. [Unpublished Masters Thesis]. University of Ghana.

Ayee, J. R. A. (2016). Manifestos and Agenda Setting in Ghanaian Elections. In Issues in Ghana's Electoral Politics (pp. 83-113). CODESRIA. https://muse.jhu.edu/book/52163

Babah, P. A., Frimpong, A., Mensah, R. O., \& Acquah, A. (2020). Computerized School Selection and Placement System in Ghana: Challenges and The Way Forward. The European Journal of Educational Sciences, 07(02), 70-80. https://doi.org/10.19044/ejes.v7no2a5

Bardach, E. (2012). A practical guide for policy analysis: The eightfold path to more effective problem solving (4th ed). SAGE.

Barro, R. J. (1999). Determinants of Democracy. Journal of Political Economy, 107(S6), S158S183. https://doi.org/10.1086/250107

Becker, G. S. (1993). Human Capital: A Theoretical and Empirical Analysis with Special Reference to Education (3rd ed.). University of Chicago Press.

Bonney, E. (2021, March 6). Registration of private candidates for BECE begins. Graphic Online. https://www.graphic.com.gh/news/education/ghana-news-registration-of-privatecandidates-for-bece-begins.html

Bray, M. (2007). Governance and Free Education: Directions, Mechanisms and Policy Tensions. PROSPECTS, 37(1), 23-35. https://doi.org/10.1007/s11125-007-9017-y

Caplan, B. D. (2007). The myth of the rational voter: Why democracies choose bad policies. Princeton University Press.

Chapman, D. W., Burton, L., \& Werner, J. (2010). Universal secondary education in Uganda: The head teachers' dilemma. International Journal of Educational Development, 30(1), 77-82. https://doi.org/10.1016/j.ijedudev.2009.08.002

Citifmonline. (2015, August 28). GES begins implementation of NDC's progressive free SHS policy. Citinewsroom. https://citifmonline.com/2015/08/ges-begins-implementation-ofndcs-progressive-free-shs-policy-2/

Cooper, B. S., Fusarelli, L. D., \& Randall, E. V. (2004). Better policies, better schools: Theories and applications. Allyn and Bacon.

Cooper, H., Valentine, J. C., Charlton, K., \& Melson, A. (2003). The Effects of Modified School Calendars on Student Achievement and on School and Community Attitudes. Review of Educational Research, 73(1), 1-52. https://www.jstor.org/stable/3516042

Creswell, J. W. (1998). Qualitative Inquiry and Research Design: Choosing among Five Traditions. SAGE Publications, Inc.

Duflo, E., Dupas, P., \& Kremer, M. (2017). The Impact of Free Secondary Education: Experimental Evidence from Ghana [Working Paper]. https://www.povertyaction.org/printpdf/6446

Essuman, A. (2018). The Challenge of Fee-Free Secondary Education and Educational Access in Ghana: A Reflection on the Past, Realities and Feasible Choices. Journal of Education 
and Practice, 9(18), 21-31.

https://www.iiste.org/Journals/index.php/JEP/article/view/43108

Frempong, K. D. (2020). Analysis of the Pre-2020 General Elections Survey.

https://www.graphic.com.gh/images/2020/nov/26/DEPARTMENT_OF_POLITICAL_S

CIENCE_PRE_2020_ELECTIONS_SURVEY_ANALYSIS.pdf

Frimpong, E. D. (2017). WAEC releases 2017 WASSCE results. Graphic Online.

https://www.graphic.com.gh/news/general-news/waec-releases-2017-wassce-results.html

GES. (2021). Postponement of Reopening Date For SHS 3 Students. Ghana Education Service

(GES). https://ges.gov.gh/2021/04/06/postponement-of-reopening-date-for-shs-3students/

Ghana. (1993). Constitution of the Republic of Ghana. Ghana Publishing Company.

Ghanaweb. (2020, August 29). NPP govt making education fit for purpose-Adutwum.

GhanaWeb. https://www.ghanaweb.com/GhanaHomePage/NewsArchive/NPP-govtmaking-education-fit-for-purpose-Adutwum- 1046200

Graves, J. (2010). The academic impact of multi-track year-round school calendars: A response to school overcrowding. Journal of Urban Economics, 67(3), 378-391. https://doi.org/10.1016/j.jue.2009.11.004

Haddad, W. D., \& Demsky, T. (1994). The dynamics of education policymaking: Case Studies of Burkina Faso, Jordan, Peru, and Thailand. The World Bank. https://doi.org/10.1596/08213-2660-0

Haddad, W. D., \& Demsky, T. (1995). Education policy-planning process: An applied framework. UNESCO, International Institute for Educational Planning.

Harber, C. (2002). Education, Democracy and Poverty Reduction in Africa. Comparative Education, 38(3), 267-276. https://doi.org/10.1080/0305006022000014133

Heyneman, S. P. (2003). The history and problems in the making of education policy at the World Bank 1960-2000. International Journal of Educational Development, 23(3), 315337. https://doi.org/10.1016/S0738-0593(02)00053-6

Hunt, F. M. (2008). Dropping Out from school: A Cross Country Review of Literature. CREATE.

IEPA-UCC. (2019). Engage Stakeholders in Educational Policies before Implementation Discussants. Institute for Educational Planning and Administration (IEPA-UCC). https://iepa.ucc.edu.gh/news/engage-stakeholders-educational-policies-implementationdiscussants

Kale-Dery, S. (2020, November 26). Govt releases $\mathrm{GH} \phi 354 \mathrm{~m}$ as professional devt allowance for teachers. Graphic Online. https://www.graphic.com.gh/news/education/ghana-news-govtreleases-gh-354m-as-professional-devt-allowance-covers-all-teachers.html

Kingdon, J. W. (2013). Agendas, Alternatives, and Public Policies (2nd ed.). Pearson Education Limited. 
Lewin, K. M. (2009). Access to education in sub-Saharan Africa: Patterns, problems and possibilities. Comparative Education, 45(2), 151-174. https://doi.org/10.1080/03050060902920518

Lindblom, C. E. (1958). Policy Analysis. The American Economic Review, 48(3), 298-312. http://www.jstor.org/stable/1809767

Lindblom, C. E. (1959). The Science of 'Muddling Through'. Public Administration Review, 19(2), 79-88. https://doi.org/10.2307/973677

Little, A. W., \& Lewin, K. M. (2011). The policies, politics and progress of access to basic education. Journal of Education Policy, 26(4), 477-482. https://doi.org/10.1080/02680939.2011.555004

Matey, J. (2020). The Effect of Free Senior High School Policy on the Lives of Parents and Wards in Ghana. International Research Journal of Multidisciplinary Scope, 1(SI-2), 2736. https://doi.org/10.47857/irjms.2020.v01si02.038

Mensah, D. K. D. (2019). Teachers' Perspective on Implementation of the Double Track Senior High School System in Ghana. International Journal of Emerging Trends in Social Sciences, 5(2), 47-56. https://doi.org/10.20448/2001.52.47.56

MoE. (n.d.). Free SHS Policy. Ministry of Education (MoE). Retrieved 16 May 2021, from https://moe.gov.gh/free-shs-policy/

MoE. (2015). Education sector performance report. Ministry of Education (MoE).

MoE. (2017). Education sector performance report. Ministry of Education (MoE).

MoE. (2018a). Education Sector Analysis. Ministry of Education (MoE).

MoE. (2018b). Implementation of Free SHS Programme and the Double Track System. Ministry of Education (MoE). http://moe.gov.gh/edge/content/uploads/2018/10/GES-COUNCILPRESENTATION-Copy.pdf

MoE, \& GES. (2021). Semester Fees for 2020 Financial Year-Free SHS. Ministry of Education (MoE) and Ghana Education Service (GES), Accra: Ghana.

MoF. (2015). The Budget Statement and Economic Policy-2016 Financial year. Ministry of Finance (MoF), Accra-Ghana. https://mofep.gov.gh/sites/default/files/budgetstatements/2016-Budget-Statement.pdf

Mohammed, A. K., \& Kuyini, A. B. (2021). An evaluation of the Free Senior High School Policy in Ghana. Cambridge Journal of Education, 51(2), 143-172. https://doi.org/10.1080/0305764X.2020.1789066

Molyneaux, K. J. (2011). Uganda's Universal Secondary Education Policy and its Effect on 'Empowered' Women: How Reduced Income and Moonlighting Activities Differentially Impact Male and Female Teachers. Research in Comparative and International Education, 6(1), 62-78. https://doi.org/10.2304/rcie.2011.6.1.62

MyJoyOnline. (2018). FREE SHS: Parents Have Been Poorly Briefed. Modern Ghana. https://www.modernghana.com/news/871714/free-shs-parents-have-been-poorlybriefed.html 
MyJoyOnline. (2019). Ghana to rejoin global student assessment group in 2021-Deputy Education Minister [News]. Joy Online. https://www.myjoyonline.com/ghana-to-rejoinglobal-student-assessment-group-in-2021-deputy-education-minister/

NAYRE. (2000). Year-Round Education Statistics. National Association for Year-Round Education (NAYRE). http://web.archive.org/web/20000305202518/www.nayre.org/stats.htm

NDC. (2012). National Democratic Congress 2012 Manifesto. National Democratic Congress (NDC), Accra-Ghana.

NDPC. (2017). 'Quality education a key component of Free SHS policy' - President AkufoAddo. National Development Planning Commission. https://www.ndpc.gov.gh/news/1285/

NPP. (2008). New Patriotic Party 2008 Manifesto. New Patriotic Party (NPP), Accra: Ghana. Nyabor, J. (2019, August 7). Allow capable parents to pay for free SHS - IEA Director. Citinewsroom. https://citinewsroom.com/2019/08/allow-capable-parents-to-pay-for-freeshs-iea-director/

Opoku Prempeh, M. (2019). Implementation of Free SHS Programme by Hon. Minister for Education. Parliament of Ghana: Accra. http://ir.parliament.gh/bitstream/handle/123456789/1250/330628101521_0001.pdf?seque nce $=1 \&$ is Allowed $=\mathrm{y}$

Pajibo, E., \& Tamanja, E. M. J. (2017). Influence and Challenges of the Capitation Grant on Education Delivery in Basic Schools in Ghana. Asian Journal of Education and Training, 3(1), 53-63. https://doi.org/10.20448/journal.522.2017.31.53.63

Ragin, C. C. (2014). The comparative method: Moving beyond qualitative and quantitative strategies. University of California Press.

Republic of Ghana. (2017, September 12). President Akufo-Addo Launches Free SHS Policy. The Presidency: Republic of Ghana. https://presidency.gov.gh/index.php/briefingroom/news-style-2/364-president-akufo-addo-launches-free-shs-policy

Sabates, R., Akyeampong, K., Westbrook, J., \& Hunt, F. (2010). School Drop out: Patterns, Causes, Changes and Policies (Education for All Global Monitoring Report 2011 2011/ED/EFA/MRT/PI/08). Centre for International Education.

Shuaibu, M., \& Oladayo, P. T. (2016). Determinants of human capital development in Africa: A panel data analysis. Oeconomia Copernicana, 7(4), 523-549. https://doi.org/10.12775/OeC.2016.030

Teye-Cudjoe, A. (2018, July 14). WAEC releases 2018 provisional WASSCE results. Ghana Business News. https://www.ghanabusinessnews.com/2018/07/14/waec-releases-2018provisional-wassce-results/

Torraco, R. J. (2005). Writing Integrative Literature Reviews: Guidelines and Examples. Human Resource Development Review, 4(3), 356-367. https://doi.org/10.1177/1534484305278283 
UIS. (2021). UIS Statistics | Dataset. UNESCO Institute for Statistics (UIS).

http://data.uis.unesco.org/\#

WAEC. (2019). Release of Provisional Results for The WASSCE for School Candidates. The West Africa Examinations Council (WAEC-Ghana). https://www.waecgh.org/article/57/release-of-provisional-results-for-the-wassce-forschool-candidates-2019/

WAEC. (2021a). BECE Private-The West African Examinations Council. The West Africa Examinations Council (WAEC-Ghana). https://www.waecgh.org/bece-private WAEC. (2021b). The West African Senior School Certificate Examination for School Candidates. WASSCE School - The West African Examinations Council (WAEC) Ghana. https://www.waecgh.org/wassce

World Bank. (2009). Abolishing school fees in Africa: Lessons from Ethiopia, Ghana, Kenya, Malawi, and Mozambique. World Bank.

World Bank. (2014). Ghana Secondary Education Improvement Project. World Bank Group. http://documents.worldbank.org/curated/en/791261468283132838/Ghana-SecondaryEducation-Improvement-Project

Yanney, V. (2018). Delayed payment of third term (2017/2018) Free SHS grant to Senior High Schools. Conference of Heads of Assisted Secondary Schools (CHASS), Stadium-Accra: Ghana.

\section{APPENDICES}

SUPPLEMENTARY A: Semester Fees for 2020 Financial Year - Free SHS

SUPPLEMENTARY B1: Video - Excerpts of the Launch of Progressively Free Senior High School Policy

SUPPLEMENTARY B2: Video - Excerpts of the Launch of Free Senior High School Policy 